\title{
Growth and Development of Underfives in Marunda Area in North Jakarta
}

Titi Sunarwati Sularyo

\begin{abstract}
Abstrak
Telah dilakukan suatu penelitian prospektif pada 102 balita di Marunda Jakarta Utara. Penelitian dilakukan dengan melakukan kunjungan rumah, meliputi status pertumbuhan dan perkembangan balita tersebut serta faktor-faktor yang berhubungan. Umur rata-rata balita adalah 31.8 bulan, termasuk umur ideal balita untuk diteliti pertumbuhan dan perkembangannya. Status pertumbuhan, baik sangat kurang memuaskan karen terhadap umur maupun panjang badan terhadap umur, serta status perkembangan ketiga-tiganya masih Khususnya mengenai perkembangan, urutan perolehan sektor perkembangan dari balita tersebut berada di bawah norma-norma baku. sektor personal sosial, sektor bahasa dan, dengan pertumbuhan dan perkembangan adalah sektor motor halus-adaptif. Faktor-faktor yang secara bermakna berhubungan faktor-faktor tersebut didapatkan juga masih kurang. Pertumbuhan pemberian ASI, pola reproduksi ibu dan pendidikan ibu. Semua sensitif dalam hubungannya dengan perkembangan. Pertumbuhan, dengan parameter berat badan terhadap umur, ternyata lebih
\end{abstract}

\begin{abstract}
A prospective study on 102 underfives in Marunda, North Jakarta was performed in terms of the growth and development and the probable related factors. It was found that the mean age of studied children (31.8 months) was the ideal age for growth \& development investigations. The growth, using the weight for age as well as the length or height for age parameters, and also the development were of the development sectors (from easiest $1.2 \%$ and $36.3 \%$ of them were found below the normal norms. The order of achievements motor-adaptive. Factors significantly related to the growh an as follows: gross motor, personal social, language, and last fine reproductive pattern and mother's ' weight for age parameter was found length for age parameter.
\end{abstract}

Keywords : Growth, development, feeding pattern, breastfeeding pattern, mother's reproductive pattern, mother's schooling.

\section{INTRODUCTION}

In Indonesia, like in other developing countries, environmental factors causing deviations in the process of the underfive's growth and development are still frequently found, in the health and biomedical as well as in the socio-economic- cultural aspects, all of which have poverty and underdevelopment as background causes. The health-biomedical aspect includes risk factors during pregnancy and delivery (prenatal, natal, perinatal risks) as well as postnatal factors of which nutrition and infections play an important role. In this regard mother's reproductive pattern and educational level cannot be neglected. In the psycho-socio-cultural field those two last mentioned factors and rearing

Department of Child Health, University of Indonesia Medical School, Jakarta, Indonesia styles with lack of mental stimulation for underfives are also still common. ${ }^{1,2}$

Many investigations reveal that all those factors mentioned above result in deviations in the child's growth and development especially during the first five years, with all its serious repercussions. From this all it follows that it is very important to detect as early as possible any abnormality in the growth and development of the underfive so as to be able to perform early intervention measures with the hope that the growth and development will resume normally. The earlier the detection, the earlier the intervention can be performed and the prognosis will hopefully be much better. ${ }^{1-4}$ In 1981 Frankenburg et al. invented the Denver Developmental Screening Test (DDST); it is a test to screen developmental deviations for underfives, a tool fulfilling all the criteria of a good screening method. This 
method can easily and quickly be performed, is reliable and valid. The DDST can effectively identify $85 \%$ $100 \%$ of underfives with developmental delays. On further follow-up it revealed that $89 \%$ of the group of underfives with abnormal DDST fail at school 5-6 years later. ${ }^{5-8}$ Thus assessing the growth and development of the underfives and early detecting abnormalities so as to be able to early intervene when needed are of great importance for the child.

The purpose of this paper is to evaluate underfives in Marunda, a rural coastal area in North Jakarta concerning their growth and development and what environmental factors relate to them.

\section{METHODS}

This study was conducted prospectively in the year 1986 on underfives aged 6 to $<60$ months chosen at random, who lived in a coastal rural area in Marunda, North Jakarta. The investigations conducted on the child consisted of measurement of body weight for age, body length or height for age, general physical examination, the Denver Development Screening Test (DDST), and interview with the child's mother in terms of environmental factors that might probably have influence on the child's growth and development such as mother's and father's educational level, mother's reproductive pattern, family income, child's feeding pattern, breastfeeding, number of underfives, morbidity and immunization status of child, the presence of educative playthings, verbal communication etc.

Parental educational level was considered poor when they never had any schooling at all. Family income was considered poor when the total family income was Rp. 15,000.00 or less per capita per month. A good immunization status was considered when at the age of less than 14 months the child had had once BCG, 3 times DTP and Polio, or when the child was less than 14 months the immunization was already performed according to the schedule.

The child's growth status I was good when the child's weight was between the 97th and 3rd centile of NCHS (National Center for Health Statistics) chart. Growth status II was good when the child's length or height was between the 97th and 3rd centile of NCHS chart. The child's development status was considered good when the DDST was normal. The child feeding pattern was good when it was according to the standard schedule and the breastfeeding pattern was good when during the first 4 months the child got only breastfeeding. The KMS utilization was good when the weight for age curve was graphically plotted on the weight chart of the KMS. Mother's reproductive pattern was named as good when the reproductive score was 5-6, and poor when it was $\leq 4$.

Table 1. Mother's reproductive pattern scoring

Maternal score by age at first birth

\begin{tabular}{lc}
\hline Maternal age $(\mathrm{yr})$. & Score \\
\hline$<18$ & 0 \\
$18-$ & 1 \\
$20-$ & 2 \\
$31-$ & 1 \\
\hline
\end{tabular}

Maternal score by interval

\begin{tabular}{lc}
\hline Interval (yr.) & Score \\
\hline$<2$ & 0 \\
$2-$ & 1 \\
$3-$ & 2 \\
$\geq 4$ & 1 \\
\hline
\end{tabular}

Maternal score by parity

\begin{tabular}{lc}
\hline No of children & Score \\
\hline $1-3$ & 2 \\
$4-5$ & 1 \\
$\geq 6$ & 0 \\
\hline
\end{tabular}

\section{Data recording and analysis}

After having been coded and edited, the results and data of all examinations and interviews of home visits were statistically analyzed at the Community Medicine Data Analysis Laboratory, University of Indonesia Medical School. Out of the quantitative data the mean values and standard deviations were given. Significance tests were also made to compare the groups, by the chi-square, Fisher, and Kolmogorov-Smirnov tests with a $p$ value of $0,05(5 \%)$ for being significant and $0,01(1 \%)$ for being very significant. For analyzing the multiple influences of various independent on the dependent variables the multiple regression analyses were made by the stepwise approach of the standard statistical formula. 


\section{RESULTS AND DISCUSSION}

Marunda was a rural coastal area about $30 \mathrm{~km}$ away from Jakarta. The total population was 5000 people, $40 \%$ were under the age of 15 years with 500 underfives. The total area was $7.46 \mathrm{~km}$ square thus the population density was 760 people/km square. There were many fish ponds found owned by the so called "juragans" or landlords who lived in Jakarta city.

Most of the mothers under study were housewives, $88.2 \%$ of them had low education. While most of the fathers were fishermen working as laborers at the fish ponds they did not own themselves. The family income was low, to wit the average income to be Rp. 13,287.00 per capita per month.

The number of the children included in this study was 102 underfives, out of which 43 were girls and 59 boys. The ages ranged from 6 months to $<60$ months. See Table 2.

Table 2. Distribution of Children by Age Group

\begin{tabular}{ccc}
\hline Age (months) & Number & Percentage \\
\hline $6-$ & 19 & 18.6 \\
$12-$ & 24 & 23.5 \\
$24-$ & 16 & 15.8 \\
$36-$ & 29 & 28.4 \\
$48-<60$ & 14 & 13.7 \\
\hline Total & 102 & 100.0 \\
\hline
\end{tabular}

The mean age of the children under study was 31.8 (SD 16.3) months. Thus it belonged to the ideal age as was stated by Pechevis that the ideal age for underfives to be investigated on their growth and development was $12-36$ months. $^{4}$

Table 3. Distribution of Children by Nutritional Status

\begin{tabular}{lcc}
\hline Nutritional Status & No & Percentage \\
\hline Well-nourished & 57 & 55.9 \\
Undernourished & 36 & 35.3 \\
Severely undernurished & 9 & 8.8 \\
\hline Total & 102 & 100.0 \\
\hline
\end{tabular}

Table 3 shows that from all the 102 children, 57 (55.9 $\%)$ were in good nutritional states, $36(35.3 \%)$ were malnourished and $9(8.8 \%)$ were severely mal- nourished. So the figure of malnourishment in this study $(35.3 \%)$ was more than three times higher than the general figure of malnutrition in underfives in Indonesia, i.e., $11.1 \%$. The proportion of severe malnutrition was also much higher than that in general in Indonesia, namely $8.8 \%$ vs $1.7 \% .^{10}$

\section{Growth status I (body weight for age parameter)}

Table 4 reveals that 57 children $(55.9 \%$ ) had a good growth status (growth status I) and $45(44.1 \%$ ) had a poor growth status.

Table 4. Distribution of Studied Children by Growth status I*

\begin{tabular}{lcc}
\hline Growth Status I & No & Percentage \\
\hline Good & 57 & 55.9 \\
Poor & 45 & 44.1 \\
\hline Total & 102 & 100.0 \\
\hline
\end{tabular}

* Growth Status I : body weight for age parameter

Table 5. Distribution of Growth Status I by Influencing Factors

\begin{tabular}{|c|c|c|c|}
\hline \multirow{2}{*}{ Factors } & \multicolumn{2}{|c|}{ Growth Status I } & \multirow{2}{*}{$\mathrm{p}$ value } \\
\hline & Good & Poor & \\
\hline \multicolumn{3}{|l|}{ No of underfives: } & $>0.05$ \\
\hline-1 & 14 & 11 & \\
\hline$->1$ & 43 & 34 & \\
\hline \multicolumn{3}{|l|}{ Immunization status } & $>0.05$ \\
\hline$-\operatorname{good}$ & 12 & 8 & \\
\hline - poor & 45 & 37 & \\
\hline \multicolumn{3}{|l|}{ KMS utilization : } & $>0.05$ \\
\hline$-\operatorname{good}$ & 12 & 5 & \\
\hline - poor & 45 & 40 & \\
\hline \multicolumn{3}{|c|}{ Mother's reproductive pattern } & $>0.05$ \\
\hline- good & 10 & 9 & \\
\hline - poor & 47 & 36 & \\
\hline \multicolumn{3}{|l|}{ Feeding pattern } & $<0.01$ \\
\hline$-\operatorname{good}$ & 35 & 15 & \\
\hline - poor & 22 & 30 & \\
\hline \multicolumn{3}{|l|}{ Family income } & $>0.05$ \\
\hline - adequate & 24 & 19 & \\
\hline - inadequate & 33 & 26 & \\
\hline \multicolumn{3}{|l|}{ Mother's education } & $>0.05$ \\
\hline - sufficient & 45 & 35 & \\
\hline - insufficient & 12 & 10 & \\
\hline \multicolumn{3}{|l|}{ Breastfeeding pattern } & $>0.05$ \\
\hline- good & 49 & 37 & \\
\hline -poor & 8 & 8 & \\
\hline
\end{tabular}


Table 5 indicates that the child's growth status I, also meaning the child's nutritional status, was very significantly related to the child's feeding pattern ( $p<$ 0.01 ). This finding was also supported by the results of the multiple regression analysis of the growth status I by those confounding factors resulting in the fact that the growth status I comprised partially $28 \%$ of the feeding pattern when the other factors were held constant. All these seem to be very logical, and similar findings were also reported by other investigators. ${ }^{3,4}$

Growth status II (linear growth, stature, body length or height for age parameter)

From table 6 it is clear that 60 children (58.8\%) were in a good growth status II and $42(41.2 \%)$ were in a poor growth status II.

Table 6. Distribution of Children by Growth status II*

\begin{tabular}{lcc}
\hline Growth Status $\Pi$ & No & Percentage \\
\hline Good & 60 & 58.8 \\
Poor & 42 & 41.2 \\
\hline Total & 102 & 100.0 \\
\hline
\end{tabular}

* Growth Status II : body length or height for age parameter

Table 7 shows that factors significantly related to growth status II were the child's breastfeeding pattern and nutritional status $(p<0.05)$. The multiple regression analysis of growth status II also revealed that growth status II comprised partially $36 \%$ of the breastfeeding pattern, and partially $26 \%$ of the mother's reproductive pattern respectively, when the other factors were held constant.

Table 8 shows that the breastfeeding pattern was also significantly related $(p<0.05)$ to the feeding pattern. Thus from Table 7 , the above multiple regression analysis and Table 8 one could conclude that when the child's nutritional status was good and the child got exclusive breastfeeding followed by a good feeding pattern the child would grow, per se linearly (stature), well, as had also been put forward by other authors. 11,12

That the mother's reproductive pattern played a role in constituting the growth status II (linear growth, stature) can be explained as follows: having a good reproductive pattern the mother will for a long time be healthy so that she will be able to create a stable rearing practice for her children which will in turn give the children a long lasting positive effect on the growth especially the linear growth. This is rather different with growth status I which is made of the body weight and thus be very sensitive and dynamic to go up or down acutely depending upon the child's condition and health at any one time. 9,11

Table 7. Distribution of Growth Status II by Influencing factors

\begin{tabular}{|c|c|c|c|}
\hline \multirow{2}{*}{ Factors } & \multicolumn{2}{|c|}{ Growth Status II } & \multirow{2}{*}{$\mathrm{p}$ value } \\
\hline & Good & Poor & \\
\hline \multicolumn{3}{|l|}{ No of underfives } & $>0.05$ \\
\hline-1 & 17 & 8 & \\
\hline$->1$ & 43 & 34 & \\
\hline \multicolumn{3}{|l|}{ Immunization status } & $>0.05$ \\
\hline - good & 10 & 10 & \\
\hline - poor & 50 & 52 & \\
\hline \multicolumn{3}{|l|}{ KMS utilization } & $>0.05$ \\
\hline - good & 9 & 8 & \\
\hline - poor & 51 & 34 & \\
\hline \multicolumn{3}{|l|}{ Mother's reproduction } & $>0.05$ \\
\hline- good & 15 & 4 & \\
\hline - poor & 45 & 38 & \\
\hline \multicolumn{3}{|l|}{ Feeding pattern } & $>0.05$ \\
\hline - good & 33 & 17 & \\
\hline - poor & 27 & 25 & \\
\hline \multicolumn{3}{|l|}{ Family income } & $>0.05$ \\
\hline - adequate & 26 & 17 & \\
\hline - inadequate & 34 & 25 & \\
\hline & $>0.05$ \\
\hline - sufficient & 48 & 32 & \\
\hline - insufficient & 12 & 10 & \\
\hline \multicolumn{3}{|l|}{ Breastfeeding pattern } & $<0.05$ \\
\hline- good & 55 & 31 & \\
\hline - poor & 5 & 11 & \\
\hline \multicolumn{3}{|l|}{ Nutritional status } & $<0.05$ \\
\hline$-\operatorname{good}$ & 40 & 17 & \\
\hline - poor & 20 & 25 & \\
\hline
\end{tabular}

Table 8. Distribution of Feeding Pattern by Breast-feeding Pattern

\begin{tabular}{lrrr}
\hline & \multicolumn{2}{l}{ Feeding Patterm } & \multirow{2}{*}{ p value } \\
\cline { 2 - 2 } & Good & Poor & \\
\hline $\begin{array}{c}\text { Breastfeeding pattern } \\
\text { good }\end{array}$ & 38 & 48 & $<0.05$ \\
poor & 12 & 4 & \\
\hline
\end{tabular}

\section{Development status}

As has been mentioned before the development status of the child was determined by the DDST findings (see Table 9). 
Table 9. Distribution of Studied Children by Developmental Status

\begin{tabular}{lcc}
\hline Development Status & No & Percentage \\
\hline Normal & 65 & 63.7 \\
Abnormal & 37 & 36.3 \\
\hline Total & 102 & 100.0 \\
\hline
\end{tabular}

There were 65 children (63.7\%) who had normal development status while 37 (36.3\%) were abnormal.

Table 10. Distribution of Developmental Status by Influencing Factors

\begin{tabular}{|c|c|c|c|}
\hline \multirow{2}{*}{ Factors } & \multicolumn{2}{|c|}{ Development Status } & \multirow{2}{*}{$p$ value } \\
\hline & Normal & Abnormal & \\
\hline No of underfives in family & & & $>0.05$ \\
\hline$-<1$ & 19 & 6 & \\
\hline$->1$ & 46 & 31 & \\
\hline Educative playthings & & & $>0.05$ \\
\hline - adequate & 4 & 5 & \\
\hline - inadequate & 61 & 32 & \\
\hline Mother's reproduction & & & $>0.05$ \\
\hline$-\operatorname{good}$ & 10 & 9 & \\
\hline -poor & 55 & 28 & \\
\hline Feeding pattern & & & $>0.01$ \\
\hline - good & 43 & 7 & \\
\hline - poor & 22 & 30 & \\
\hline Family income & & & $>0.05$ \\
\hline - adequate & 29 & 14 & \\
\hline - inadequate & 36 & 23 & \\
\hline Mother's education & & & $>0.05$ \\
\hline - sufficient & 57 & 23 & \\
\hline - insufficient & 8 & 14 & \\
\hline Nutritional status & & & $>0.01$ \\
\hline- good & 45 & 12 & \\
\hline - poor & 20 & 25 & \\
\hline Verbal communication & & & $>0.05$ \\
\hline - adequate & 25 & 14 & \\
\hline - inadequate & 40 & 23 & \\
\hline Breast-feeding & & & $>0.05$ \\
\hline - good & 52 & 34 & \\
\hline - poor & 13 & 3 & \\
\hline Educative playthings & & & $>0.05$ \\
\hline - adequate & 4 & 5 & \\
\hline - inadequate & 61 & 32 & \\
\hline
\end{tabular}

From Table 10 it seems that factors which were statistically significantly related to the child's development status were mother's education ( $p<0.05)$, nutritional status $(p<0.01)$, and feeding pattern $(p<0.01)$. The multiple regression analysis supported also the above mentioned finding as it revealed that the development status comprised of partially $33 \%$ the feeding pattern, partially $27 \%$ the nutritional status and partially $26 \%$ mother's education when the other factors were held constant.

It was reasonable that the development status was determined by the feeding pattern, the nutritional status and the mother's education. A good feeding pattern promotes a good nutritional status which in turn leads to a secure prepared constitution that is conducive to receive and digest the mental stimulation given from the environment.

A mother with a proper, sufficient education will make herself competent to create a rearing practice with early, abundant stimulation (rich verbal communication, the presence of proper educative playthings etc.) needed by the child to develop optimally. Such a mother has also a positive role in promoting the child's nutritional status as she knows to select a variable but nutritious menu for her child that will enhance the child's nutritional status in a positive way.

Table 11. Relationship between Growth Status I and Growth Status II of Studied Children

\begin{tabular}{llll}
\hline & \multicolumn{2}{l}{ Growth Status II } & p value \\
\cline { 2 - 3 } & good & poor & \\
\hline Growth status I : & & & \\
- good & 40 & 17 & P $<0.05$ \\
- poor & 20 & 25 & \\
\hline
\end{tabular}

Table 11 indicates that the growth status I (body weight for age parameter) was significantly related to the growth status II (the linear growth or body length for age parameter, $p<0.05$ ). So either the body weight for age parameter (growth status I) or the body length for age parameter (growth status II, per se the linear growth, stature) both reflected well enough in this study the growth of the child.

Table 12. Relationship between Growth Status II and Development Status of Studied Children

\begin{tabular}{lccc}
\hline & \multicolumn{2}{c}{ Development Status } & \\
\cline { 2 - 2 } & Normal & Abnormal & \\
\hline Growth Status II : & & & \\
- Good & 43 & 17 & $>0.05$ \\
- Poor & 22 & 20 & \\
\hline
\end{tabular}


Table 13. Relationship between Growth Status I and Development Status of Studied Children

\begin{tabular}{lccc}
\hline & \multicolumn{2}{c}{ Development Status } & p value \\
\cline { 2 - 2 } & Normal & Abnormal & \\
\hline Growth Status I & & & \\
- Good & 45 & 12 & $<0.01$ \\
- Poor & 20 & 25 & \\
\hline
\end{tabular}

As there was no significant relationship $(p>0.05)$ between the growth status II and the development status (Table 12) while Table 13 reveals contrariwise that there was a very significant relationship $(p<0.01)$ between the growth status I and the development status, it was only reasonable to say that though growth status I as well as growth status II both were reflection of the child's growth status, the body weight for age parameter (growth status I) was in this study more sensitive for predicting the child's development. Morley and Lovel (9) also stated the underfive's weight curve to be a very sensitive instrument to be used prospectively to evaluate the child's growth and health.

\section{Detailed analyses of the development status}

In order to have more detailed information of the four sectors or areas of function of development (to wit the gross motor, language, fine motor-adaptive, and the personal social sector), their relationship with the overall development status, and the intersectoral relationships, a sensitization of the DDST had been made for each sector by raising the cut off point from the original DDST to become no delay $(D=0)$ and the existence of one or more delays $(D \geq 1)$ in each sector.

Table 14. Distribution of Development Sector by Delay in Each Sector

\begin{tabular}{lrc}
\hline Sector & No & Percentage \\
\hline Gross motor & & \\
- D = 0 & 79 & 77.5 \\
- D $\geq 1$ & 23 & 22.5 \\
- Total & 102 & 100.0 \\
Personal social & & \\
- D = & 72 & 70.6 \\
- D $\geq 1$ & 30 & 29.4 \\
- Total & 102 & 100.0 \\
Language & & \\
- D = & 64 & 62.7 \\
- D $\geq 1$ & 38 & 37.3 \\
- Total & 102 & 100.0 \\
Fine motor-adaptive & & \\
- D = 0 & 51 & 50.0 \\
- D $\geq 1$ & 51 & 50.0 \\
- Total & 102 & 100.0 \\
\hline
\end{tabular}

Table 15. Distribution of Overall Development Status by Development Sector

\begin{tabular}{lccc}
\hline \multirow{2}{*}{ Development sector } & \multicolumn{2}{c}{ Overall Development Status } & \multirow{2}{*}{ p value } \\
\cline { 2 - 3 } & Normal & Abnormal & \\
\hline Gross motor & & & $<0.01$ \\
$-D=0$ & 59 & 20 & \\
$-D \geq 1$ & 6 & 17 & \\
Personal Social & & & $<0.01$ \\
$-D=0$ & 58 & 14 & \\
$-D \geq 0$ & 7 & 23 & \\
Language & & & $<0.01$ \\
- D $=0$ & 55 & 9 & \\
- D $\geq 1$ & 10 & 28 & \\
Fine motor-adaptive & & & $<0.01$ \\
- D $=0$ & 50 & 1 & \\
- D $\geq 1$ & 15 & 36 & \\
\hline
\end{tabular}

From Tables 14 and 15 it is clear that the easiest development sector to be accomplished was the gross motor sector, followed respectively by the personal social sector, then the language sector and the last and so most difficult sector to be reached was the fine motor-adaptive sector.

As mentioned before (see Table 9) out of the total of 102 underfives $37(36.3 \%)$ had development disturbances. Furthermore (see Table 16) $50.0 \%$ of children had delays in the fine motor-adaptive sector, $37.3 \%$ in the language sector, $29.4 \%$ in the personal social sector and $22.5 \%$ in the gross motor sector.

Table 16. Distribution of Children by Development Delay in the Four Sectors

\begin{tabular}{lcc}
\hline Sector with delay & No & $\begin{array}{l}\text { Percentage of } \\
\text { studied children }\end{array}$ \\
\hline Gross motor & 23 & 22.5 \\
Personal social & 30 & 29.4 \\
Language & 38 & 37.3 \\
Fine motor-adaptive & 51 & 50.0 \\
\hline
\end{tabular}

As mentioned before the order of accomplishment of the development sectors was respectively the gross motor, the personal social, the language and last the fine motor-adaptive sector (Table 16). This all can be explained as follows: The gross motor development sector (supine to prone position, creeping, crawling, sitting, standing, walking etc.) was in its earliest stages for a great part determined by the child's own instinct, drive or inner motivation for exploration and widening the world around without needing the environment to 
stimulate her/him specially on purpose. ${ }^{13,14}$ Thus in this study this sector was easiest to be accomplished.

The personal social development sector depends much on the fulfillment of the emotional needs and affection which in very young children is easily met as they look cute, are cuddlesome, are still very dependent etc. So for the parents it is their natural instinct and spontaneity to be close and be attached to their very young. ${ }^{13}$ So this development sector was found next to be reached.

The language development sector depends on the richness of the language and verbal communication used to or around the child, whether or not the child is, so as to say, bathed in language (9). In this study the proper verbal communication occurred only in 38 children $(38.2 \%)$, so this sector was reached in a more difficult order of accomplishment.

The fine motor-adaptive development sector was the most difficult to reach as it depends on the provision of stimulation, usually on purpose, from the environment, like the provision of proper to age educative playthings and so on. In this study age proper playthings were found only in a very small quantity, namely in 9 out of 102 underfives ( $8.8 \%$ ). It could have been the reason why this sector was accomplished last.

To enhance the achievements in the language and fine motor-adaptive sectors which play an important role in later on developing human resources of good quality it is very obvious that enrichment of stimulation in these too sectors a.o. provision of proper to age educative playthings and the use of abundant verbal communication, is mandatory. For this self same reason also was the Bina Keluarga Balita Program (Program BKB, Underfive Family Promotion Program) formed in 1980 in Indonesia with the aim to train mothers to create a rearing practice for their underfives where the motherchild interaction is enhanced, their child's stimulation enriched and where the mother/family is able to detect early growth and development abnormalities of their child.This program is coordinated by the office of the Minister of Women's Affair while the operational competence is by the BKKBN (National Coordinating Board of Family Planning) and is at present widely spread and implemented all over the country with promising results. ${ }^{15}$

In this study it was also revealed that the overall development status was statistically very significantly related to each of its four development sectors ( $p$
$<0.01$, Table 15), while the four development sectors themselves were also very significantly related ( $\mathrm{p}<$ 0.01 ) to each other.

A multiple regression analysis was also performed to find out the roles of the development sectors in constituting the overall development status revealing that the development status comprised of partially $44 \%$ the fine motor-adaptive sector, partially $28 \%$ the language development sector and $24 \%$ the personal social sector respectively,. when the other factors were held constant. This finding once again supported the fact of how important it is to enhance stimulation in the fine motor-adaptive, language and social personal sectors of development. This once again justifies the important existence of the BKB program.

In conclusion, our data indicate the followings: (1) The growth as well as the development states of children under study were all still unsatisfactory; (2) The figures for undernutrition and severe undernutrition were much higher than the general figures for Indonesia; (3) The growth and development states were closely related to each other; (4) The growth status was influenced by feeding pattern, breast-feeding pattern, the mother's reproductive pattern; (5) The development status was influenced by nutritional status, feeding pattern and mother's schooling; (6) The order of achievement of the development sectors was the gross motor, personal social, language and the most difficult sector was the fine motor-adaptive.

\section{REFERENCES}

1. Grant JP. The status of the world's children 1995, New York: Oxford University Press, 1995; 12-34

2. Sularyo TS. Child health care with emphasis on childhood. morbidity and mortality problem. Presented at the XIth Asian Medical Students' Conference. Jakarta, July 30, 1990

3. UNICEF. Development goals and strategies for children in the 1990s. New York: UNICEF, 1990; 9-30.

4. Pechevis M. Determinants for optimal child growth and development. Presented at Kongres Nasional Ilmu Kesehatan Anak V (5th National Congress of Pediatrics), Medan, 1981.

5. Frankernburg WK, Dodds JB, Fandal AW et al. DDST (Denver Developmental Screening Test): Reference manual revised 1975 Edition, University of Colorado Medical Center, 1975

6. Frankenburg WK. The Denver approach to early identification of children at risk, 1st Ed. Plenum New York, 1985, p $135-56$

7. Frankenburg WK, Dodd J, Archer P, Shapiro H. The Denver II. A Major Revision and Restandardization of the Denver Developmental Screening Test. Pediatrics 1992; 89:91-7 
8. Soetjiningsih. Evaluation of the child's Development. In : IGN Gde Ranuh, Ed. Tumbuh kembang anak; 1st ed. Jakarta : Penerbit Buku Kedokteran EGC, 1995; 65-78

9. Morley D, Lovel M. My name is today; 1st ed. LondonBasingstoke: Mc Millan, 1986: 46-57, 84-93, 308-11

10. Leimena SL. Policy of the Ministry of Health in Promoting the Health of Underfives. Presented at the Sarasehan "Perkembangan Anak Menuju Peningkatan Kualitas Hidup Manusia" Jakarta, March 26, 1990.

11. Tanner JM. Foetus into man: Physical growth from conception to maturity. London: Open Book, 1981 : 6-51.
12. Sudiyanto. Physicobiopsychosocial environmental factors influencing the child's growth and development. In: Gizi dan tumbuh kembang. Jakarta: Bagian IKA FKUI, 1985; 56-61.

13. Pechevis M. Supervision of early childhood development (ages 0-6) in the frame of basic health services, Children in the Tropics 1974; $95: 3-24$.

14. Wall WD. Development of intelligence in early childhood. Children in the tropics 1973; 86: 3-11

15. Sularyo TS. Monitoring of the underfive's growth and development with special reference to the Bina Keluarga Balita Program. In: Samsudin, Sri S Nasar, Damayanti R Syarif (Eds). Masalah gizi ganda dan tumbuh kembang anak. Jakarta : Binarupa Aksara, 1995; 33-41 